stained with dark matter. The meshes are nearly black, but in a bright light show a fibrous texture and metallic lustre, due to pyrite.

Viewed as opaque objects under the microscope, the reticulating bands are seen to be fascicles of slender cylindrical rods or spicules varying much in diameter, some of the largest being in the narrow transverse bands. The spicules may in a few cases be seen to be tapering very gently to a point, but usually seem quite cylindrical and smooth. In their present state they appear as solid shining rods of pyrite. The largest spicules are about $\frac{1}{5.00}$ of an inch in diameter, the smaller scarcely one fourth of that size. The spicules of the transverse bands cross those of the longitudinal ones without any organic connexion. Among the long spicules of the bands can be seen multitudes of very minute and apparently short spicules confusedly disposed; and these abound also in the dark-coloured areoles.

On the whole the structures are not identical with those of any plant known to me, and rather resemble those of siliceous sponges of the genus Euplectella.

The most puzzling fact in connexion with this view is the mineral condition of the spicules, now wholly replaced by pyrite. Carbonaceous structures are often replaced in this way; and so are also calcareous shells, especially when they contain much corneous matter; but such changes are not usual with siliceous organisms. If the spicules were originally siliceous, either they must have had large internal cavities which have been filled with pyrite, or the original material must have been wholly dissolved out and its place occupied with pyrite. It is to be observed, however, that in fossil sponges the siliceous matter has not unfrequently been dissolved out, and its space left vacant or filled with other matters. I have specimens of Atylospongia from the Niagara formation which have thus been replaced by matter of a ferruginous colour; and in a bundle of fibres, probably of a sponge allied to Hyalonema, from the Upper Llandeilo of Scotland, I find the substance of the spicules entirely gone, and the spaces formerly occupied by them empty. It should be added that joints of crinoid stems and fronds of Fenestella occurring in the same specimen with the Uphantcenia are apparently in their natural calcareous state.

Though I have hitherto regarded this curious organism as a fucoid, I confess that the study of the specimen above referred to inclines me to regard it as more probably a sponge.

I owe the opportunity of examining this very interesting specimen to the kindness of Professor Whitfield.-Amer. Journ. Sci., Aug. 1881, p. 132.

\title{
Mortality of Fish in the Gulf of Mexico.
}

From notices appearing in the 'Proceedings of the United States' National Museum' it appears that for the last two years there has 
been a very serious mortality among the fish in the Gulf of Mexico near Florida, arising apparently from some peculiar condition of a belt of water at some small distance from the shore. Mr. M. A. Moore, writing on 30th November last, from Braidentown, Manatee County, Florida, to Prof. S. F. Baird, gives the following account of the facts as brought under his observation. He says:-

"You are doubtless aware that we have employed here a number of vessels as fishing-smacks, ranging from 30 to 50 tons, whose vocation it is to carry live fish to the Cuban markets. This industry provides occupation and subsistence for a large portion of our population in South Florida.

"About two years ago certain portions of our Gulf-waters became poisoned in some way that caused the death of all the fish that came in contact with it. Whenever a smack with a full fare, $i$. $e$. a full cargo, of fine healthy fish in her well sailed into this poisoned water, every fish would die, and they would have to be thrown away. This compelled the vessel to return to fishing at the loss of a month's hard work.

"This state of affairs has occurred again, the waters of some portions of the Gulf becoming so noxious as to kill the fish. The poison seems to be confined to certain localities and currents for the time being, as sometimes this state of affairs is observed more marked at one place and sometimes at another. However, there seems to be more of it about the mouth of Charlotte Harbour and off Punta Russa than elsewhere.

"Where this condition of water prevails the surface of the water is covered with dead fish, and the beach is covered with them in such numbers that sometimes the stench is intolerable.

"I live immediately on the beach of Palma Sola Bay; and some two weeks ago the beach was covered with dead fish. The only thing that seems to be inexplicable is, that this water seems to affect what are termed here bottom-fish more than any others. The principal game of the fishing-smack are the grouper (Serranus nigritis) and the snapper (Serranus erythrogaster). These, with the perch, kingfish, trout, and all those fish which take the hooks, seem to be much more affected than the mullet (Mugil lineatus) or the pompano (Bothrolcemus pampanus). . . . Numbers of sharks and rays, eels and catfish are thrown up dead on the beach. . . . . My own opinion is, that the state and condition of the water are caused by some volcanic action at the bottom."

These facts of the death of the fish in the wells of the smacks " on reaching a certain kind of water distinguishable by its colour," and of the mortality among the fish in the Gulf, are confirmed by other writers. The noxious water is said to be of a brick-red colour, and to occur over a space of 200 miles.

Various hypotheses have been put forward by local writers to account for the phenomenon. Mr. Moore, in the above letter, suggests volcanic action at the sea-bottom; and this opinion seems to be held by others. Sometimes it is put definitely, namely an 
escape of noxious gases, or of mineral substances held in solution; and the editor of the newspaper 'Forest and Stream' refers particularly to a boiling spring which is said to exist off the coast. Others suggest the action of parasitic plants; and this appears to be the opinion of Dr. F. M. Endlich, who has made an analysis of the noxious water, and reports upon it as follows:-

"Having completed the examination of sea-waters from the Gulf of Mexico, so far as the scant supply would permit, I have the honour to offer the following report thereupon, the water in which the fish die being designated as A, the good water as B :-

$\begin{array}{lll} & \text { A. } & \text { B. } \\ \text { Specific gravity ................ } & 1 \cdot 024 & 1 \cdot 022 \\ \text { Solid constituents (total), per cent... } & 4 \cdot 0780 & 4 \cdot 1095 \\ \text { Ferric compounds, per cent. } \ldots \ldots \ldots & 0 \cdot 1106 & 0 \cdot 0724 \\ \text { Injurious organic matter .......... } & \text { ratio=3 } & \text { ratio=2 }\end{array}$

"I find that the water A contains a large quantity of Algæ and Infusoria. It is eminently probable that the former may have had an injurious effect upon the fish. Specimens of the Algæ have been submitted to Professor Goode, who will send them to some expert in order that their specific character may be determined.

"The 'dead fish ' in the possession of the United States' National Museum are such that any examination of the organs of respiration will be of no avail.

"I cannot find, even by spectroscopic analysis, any mineral constituents in the water A which could noxiously affect the fish.

"In my estimation the death of fish was caused by the more or less parasitic Algæ, which are found in large quantities in water A, but do not occur at all in water $B$.

"In case the same phenomenon should recur, the presence of an expert in the questions involved, more particularly chemistry and botany, would most likely lead to definite results."

\section{Rhizopods the Food of some young Fishes.}

Dr. Leidy reports that the young of some of the Suckers (Catostomidæ), Hypentelium, Myxostoma, \&c., have been found by Mr. S. A. Forbes, of Illinois, to have the intestines packed with tests of Difflugia and Arcella, indicating that they feed on Rhizopods. In a slide containing material from the intestines of the young mullet (Myxostoma macrolepidotum) from Mackinaw Creek, prepared by Mr. Forbes, Dr. Leidy distinguished Difflugia globulosa and D. acuminata; and in another of the food of Eremyzon succetta he found Difflugia globulosa, D. lobostoma, D. pyriformis, Arcella vulgaris, and $A$. discoides, besides another peculiar undescribed form.-Amer. Journ. Science, July 1881. 


\section{$2 \mathrm{BHL}$ Biodiversity Heritage Library}

1881. "Mortality of fish in the Gulf of Mexico." The Annals and magazine of natural history; zoology, botany, and geology 8, 238-240.

https://doi.org/10.1080/00222938109487451.

View This Item Online: https://www.biodiversitylibrary.org/item/95066

DOI: https://doi.org/10.1080/00222938109487451

Permalink: https://www.biodiversitylibrary.org/partpdf/68609

\section{Holding Institution}

Harvard University, Museum of Comparative Zoology, Ernst Mayr Library

\section{Sponsored by}

Harvard University, Museum of Comparative Zoology, Ernst Mayr Library

\section{Copyright \& Reuse}

Copyright Status: Public domain. The BHL considers that this work is no longer under copyright protection.

This document was created from content at the Biodiversity Heritage Library, the world's largest open access digital library for biodiversity literature and archives. Visit BHL at https://www.biodiversitylibrary.org. 